\title{
Swimming with the fishes
}

\author{
Tokunbo Ajayi, ${ }^{1}$ Khoa Do, ${ }^{2}$ Ashmeet Bhatia, ${ }^{1}$ Avenir Mulita ${ }^{1}$
}

${ }^{1}$ North Shore Medical Center, Salem, Massachusetts, USA ${ }^{2}$ Department of

Gastroenterology, North Shore Medical Center, Salem, Massachusetts, USA

\section{Correspondence to} Dr Tokunbo Ajayi, philipekiti@yahoo.com

Accepted 4 March 2014

\section{CrossMark}

To cite: Ajayi T, Do K, Bhatia $A$, et al. BMJ Case Rep Published online: [please include Day Month Year] doi:10.1136/bcr-2013201798

\section{DESCRIPTION}

We describe the case of a healthy 23-year-old man who presented to the emergency room with a $10 \mathrm{~h}$ history of sharp left lower chest pain occasionally radiating to the epigastrium. The pain had started acutely while he was eating dinner at a restaurant in New York City and he noticed it during swallowing. The pain was initially sharp but later became dull. There were intermittent episodes of sharp pain, exacerbated by deep inspiration and swallowing. Lying on his right side alleviated the pain. $\mathrm{He}$ reported no fevers, cough, nausea or vomiting. Initial evaluation including electrocardiogram, chest $\mathrm{X}$-ray, liver function tests and an abdominal ultrasound was unremarkable.

The patient underwent urgent oesophagogastroduodenoscopy which showed a fin-like opaque foreign body protruding about $3 \mathrm{~mm}$ above the lower oesophageal mucosa (figures 1 and 2). The foreign body was removed using a cold forceps with a rubber foreign body hood protector. This foreign body was the bone of a tilapia fish which the patient had eaten at the New York restaurant (figure 3). Chest CT did not show any free or mediastinal air, abscess or fluid collection. The patient's pain resolved within a few days of removal of the fish bone.

This case describes oesophageal ulceration mimicking chest pain and highlights the importance of detailed history taking during investigation. After cardiac causes have been ruled, other causes of chest pain should be evaluated, such as pulmonary aetiology (eg, pleurisy), musculoskeletal causes (eg, costochondritis) and gastrointestinal causes (eg, peptic ulcer).

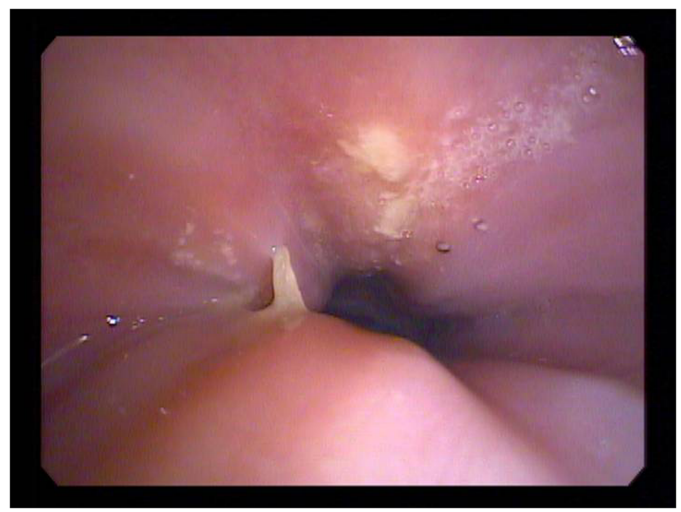

Figure 1 A fin-like opaque foreign body protrudes about $3 \mathrm{~mm}$ above the lower oesophageal mucosa.

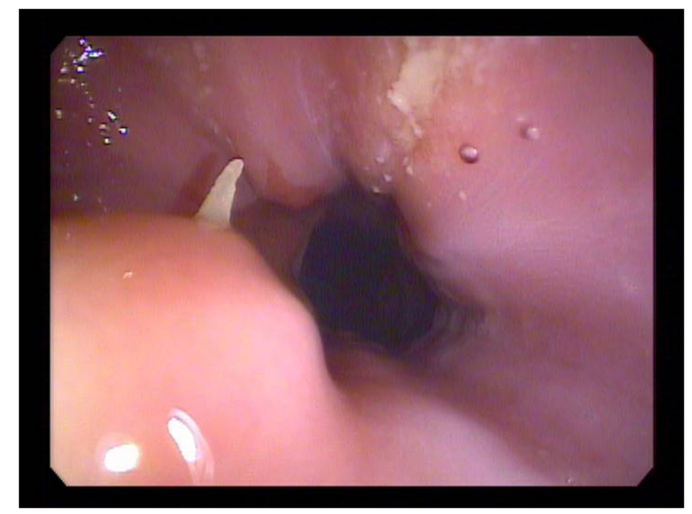

Figure 2 Ulceration is seen adjacent to the tip of the tilapia fish bone.

This case draws attention to the endoscopic dilemma in the management and removal of foreign bodies. Most (80-90\%) ingested foreign material will pass with defecation and without intervention. However, objects with sharp edges or pointed tips can have a high risk of complications of up to $35 \%{ }^{1}$ ${ }^{2}$ Objects impacted in the oesophagus require urgent removal, as in this case, to prevent perforation and other complications. ${ }^{3}$

Diagnosis and management requires proper identification of the foreign body during endoscopy to rule out an abscess or polyp. The correct device to remove the foreign body must also be chosen from among different shapes and sizes of forceps, snares, Roth baskets (a mesh net used to entrap objects) and magnets placed at the end of a scope. A detailed listing of the techniques available for extraction is outside the remit of this paper.

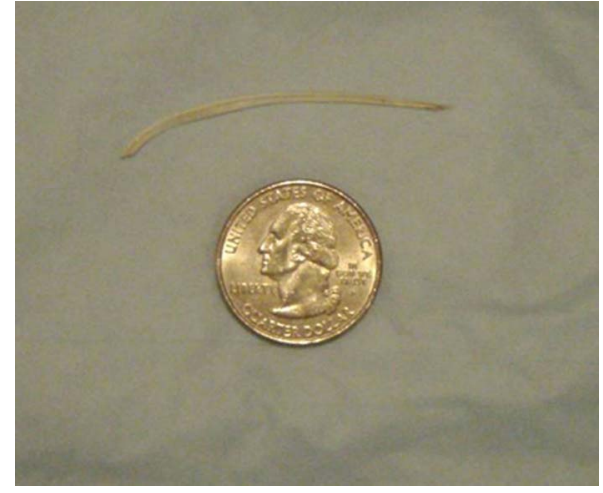

Figure 3 The tilapia fish bone is about $50 \mathrm{~mm}$ long, approximately the length of two quarters. 


\section{Learning points}

- The differential diagnoses of chest pain are many and include cardiac causes, pulmonary causes, musculoskeletal causes and gastrointestinal causes.

- Timely and expert endoscopic management of a gastrointestinal foreign body is crucial.

Contributors All authors contributed equal to this paper.

Competing interests None.
Patient consent Obtained.

Provenance and peer review Not commissioned; externally peer reviewed.

\section{REFERENCES}

1 Smith MT, Wong RK. Foreign bodies. Gastrointest Endosc Clin N Am 2007;17:361-82

2 Singh $\mathrm{P}$, Singh A, Kant $\mathrm{P}$, et al. An impacted denture in the oesophagus-an endoscopic or a surgical emergency-a case report. I Clin Diagn Res 2013;7:919-20.

3 Conway WC, Sugawa $\mathrm{C}$, Ono $\mathrm{H}$, et al. Upper Gl foreign body: an adult urban emergency hospital experience. Surg Endosc 2007;21:455-60.

Copyright 2014 BMJ Publishing Group. All rights reserved. For permission to reuse any of this content visit http://group.bmj.com/group/rights-licensing/permissions.

BMJ Case Report Fellows may re-use this article for personal use and teaching without any further permission.

Become a Fellow of BMJ Case Reports today and you can:

- Submit as many cases as you like

- Enjoy fast sympathetic peer review and rapid publication of accepted articles

- Access all the published articles

Re-use any of the published material for personal use and teaching without further permission

For information on Institutional Fellowships contact consortiasales@bmjgroup.com

Visit casereports.bmj.com for more articles like this and to become a Fellow 